\title{
A Probe into the Integration of Traditional Music Culture in Vocal Music Teaching in Colleges and Universities
}

\author{
Li Sun \\ School of Art, Yangtze University, Jingzhou, Hubei, China
}

\begin{abstract}
Under the background of the current era, comprehensively deepening the implementation of teaching reform is a key consideration for education at all levels, especially for colleges and universities. In order to carry out quality education and improve students' comprehensive literacy and professional ability, some colleges and universities have integrated traditional music culture into the vocal music teaching, and combined it with modern music art, which provides a brandnew development for vocal music teaching. At the same time, it also provides opportunities for the inheritance and promotion of traditional music culture. This article briefly expounds the significance of integrating traditional music culture into college vocal music teaching, summarizes the current problems, and proposes a positive and effective specific path, hoping to provide certain help and reference for the development of the vocal teaching activities in colleges and universities.
\end{abstract}

Key words: colleges and universities; vocal music teaching; traditional music culture; integration

\section{Introduction}

The practice of vocal music teaching in colleges and universities in our country has long attached great importance to the knowledge of Western vocal music culture, focusing on the cultivation and training of students' vocal music skills. However, my country's traditional music culture has not been paid enough attention in the teaching process, which limits the comprehensive quality of students to a large extent, and cannot effectively improve the cultural and national selfconfidence of vocal music majors. Therefore, in the new era, vocal music teaching in colleges and universities must further reform the traditional teaching methods and modes, and fully integrate traditional music culture into vocal music teaching classrooms to promote the improvement of vocal music teaching results, thereby the traditional Chinese nation music culture has been inherited and promoted.

\section{The Significance of Integrating Traditional Music Culture into College Vocal Music Teaching}

2.1 It helps to inherit and promote traditional culture

In the long historical years, the Chinese nation has accumulated countless excellent cultures, which have become our most precious spiritual wealth, and traditional music culture is one of the most important components. In different historical stages, different historical cultures can be produced and nurtured, and the traditional music of ethnic minorities also adds more charm to the overall music culture. Therefore, integrating traditional music culture into college vocal music 
teaching helps to inherit and promote traditional music culture.

\subsection{It helps to improve students' core literacy}

With the development of the times, the society's requirements for talents are not only to have certain professional capabilities, but also to have comprehensive literacy and achieve all-round development. Only when students continue to improve their core literacy can they continuously improve their competitiveness. While music literacy, as an important part of the core literacy of college students, has a good effect on cultivating sentiment and adjusting emotions. Therefore, integrating traditional music culture into vocal music teaching in colleges and universities can further strengthen students' core literacy and ability to appreciate music and feel.

\subsection{It helps to promote the harmonious development of college music}

In recent years, vocal music teaching activities in colleges and universities have increasingly shown a diversified trend. However, in the specific teaching process, many teachers still have not got rid of the traditional teaching mode and have not integrated traditional music culture into vocal music teaching, which hinders the development of college vocal music courses. Therefore, integrating traditional music culture into college vocal music teaching helps to promote the harmonious development of college music.

\section{Problems Facing the Development of Traditional Music Culture}

College music education system is an important platform for the inheritance and promotion of traditional music culture, and has played an important role in the development of traditional culture. Judging from the current curriculum structure and teaching system of music teaching in various colleges and universities, the content of traditional music culture occupies a certain proportion of teaching, but the proportion is low, and most of them are not required courses. This is mainly due to the insufficient attention paid to traditional music culture by the teaching management departments and related professional teachers. Students, as a result, have relatively few opportunities to come into contact with traditional music culture in the process of vocal music learning, and it is also difficult to complete the important task of inheriting and promoting traditional music culture. Since the 19th century, the European economy has continued to develop, and economic vitality has also brought vitality and development opportunities for the music industry. More and more outstanding musicians have begun to appear, and many music works that are popular all over the world was born. The influence of Western music has been expanding for a period of time with a huge number of listeners, which to a certain extent has led to a low proportion of traditional music in the music education system of our country's colleges and universities. In addition, many college students also prefer Western music culture today, and their knowledge and understanding of Chinese traditional music culture are far from enough. This has brought certain obstacles to the inheritance and development of traditional music culture, and is not conducive to realize national and cultural confidence. It can be seen that traditional music culture is facing the impact of western music culture and the lack of interest among youth groups in the development process.

\section{The Path to Integrate Traditional Music Culture into College Vocal Music Teaching}

4.1 Strengthen the traditional music cultural literacy of vocal music teachers

Vocal music teachers in colleges and universities are the leaders and implementers of teaching activities, and their traditional music cultural literacy directly affects the teaching effect. Therefore, it is necessary to guide vocal music teachers to pay more attention to traditional music culture, and to consciously strengthen their traditional music cultural literacy.

First of all, colleges and universities should actively organize teachers to carry out systematic learning and training of traditional music culture, so that teachers can recognize traditional music culture from the heart while learning traditional 
cultural knowledge and feeling the charm of traditional music culture. In the training process, teachers should be fully introduced to the meaning and value of traditional music culture, and be encouraged to actively integrate traditional music culture into music teaching classrooms. In addition, they can also introduce some excellent cases of integrating traditional music culture into college vocal music teaching, so that they can intuitively feel the good teaching effect, thereby increasing confidence in integrating traditional music culture to a certain extent. Secondly, teachers themselves should also strengthen their learning, continue to enrich their knowledge reserves in traditional music culture, and deepen their understanding of traditional music culture. For example, teachers can search for relevant materials, listen to lectures, watch documentaries and other film and television materials on the internet to continuously enrich themselves and improve their professional qualities. At the same time, teachers can also actively communicate with other teachers, share their experiences in the process of learning and teaching traditional music culture, discuss the problems that have been discovered, and take measures to actively solve them. In this way, teachers have enough knowledge reserves and professional qualities to integrate traditional music culture into college vocal music teaching.

\subsection{Further innovation in vocal music teaching methods}

Teaching method is an important tool for teachers to carry out teaching activities and promote the classroom process. Good teaching methods can play a multiplier role in improving teaching quality and optimizing teaching effects. Therefore, teachers should innovate the methods of vocal music teaching and choose different teaching methods according to the requirements of different teaching content and the specific conditions of students, so as to achieve the expected teaching effect. For example, teachers can use teaching methods, like experiential situational teaching method, game teaching method, layered teaching method, contrast induction method, to make the vocal music classroom lively and interesting, thereby enhancing students' motivation in learning. In terms of comparative induction, teachers can compare and summarize the different expressions of the same image in traditional music culture and Western music culture in the teaching process. This will not only allow students to clearly feel the differences between Chinese and Western music cultures, but also enable students to develop their appreciative ability, so that they can find their favorite music style in constant summary and comparison. After the class, teachers can also assign homework for them to perform interpretations on the same topic in different styles. Through this teaching method, traditional music culture can be well integrated into college vocal music teaching, and students' learning effect and ability to perceive and appreciate musical works will be significantly improved.

\subsection{Use advanced teaching technology to carry out teaching}

In the process of modern vocal music teaching, multimedia technology and electronic information technology have been fully popularized, which has greatly improved the quality and efficiency of teaching. Therefore, we should make good use of advanced teaching technology, actively carry out teaching activities, and give full play to the important role of teaching technology in creating a classroom atmosphere and enhancing students' interest in learning. In the specific teaching process, teachers should use advanced teaching technology as a medium, carefully craft courseware, sort out and summarize suitable film and television materials, audio materials, etc., in order to obtain better teaching results. In the process of introducing the relevant music and cultural background, teachers can choose video materials, which can not only attract students' interest in learning to the maximum, but also bring full and detailed introduction and popularization to students. In addition, for the part of teaching content that is difficult and students' learning quality is poor, teachers can specifically shoot teaching videos and upload them to the relevant micro-class platform, so that students can learn these important and difficult knowledge anytime and anywhere, helping them to reduce study pressure and improve learning effect. 
4.4 Enrich students' emotional experience in the teaching process

Music is the expression of the creator's emotions. Only when the performer is fully involved in the performance and feels the emotion contained in the music with his heart, can he resonate with the audience and make the music performance more contagious. In particular, my country's traditional music culture includes the music cultures of many ethnic minorities, which have strong emotions and high demands on performers. Therefore, teachers should enrich students' emotional experience during the teaching process and help them establish their own feelings and thinking about musical works in order to improve students' learning effects and help them better present musical works. For example, when a teacher teaches a certain piece of music, he can fully explain the background of the piece of music, the social form involved, the artistic and cultural features contained therein, so that students can have a comprehensive and in-depth understanding of the work, so as to help them find the emotional connotation in the work more quickly, and make them have an accurate grasp of the work.

4.5 Choosing appropriate music works to cultivate students' perception ability

Integrating traditional music culture into vocal music teaching in colleges and universities also requires teachers to screen the musical works included in the teaching content, select appropriate musical works to cultivate and train students' perceptual ability, so that their understanding and perception of music works are enhanced. In the specific selection process, teachers should choose representative music works and traditional music works that are compatible with the teaching theme, so as to help students establish connections between different types of music, accurately analyze the differences, and master them skillfully. In this process, teachers should also pay attention to the cultivation of students' cultural and humanistic qualities, so that they have stronger emotional understanding and expression skills, so as to better feel and express musical works. With suitable music works, students will have a better experience and feelings in the learning process, which helps them to accurately grasp the characteristics of different music genres, thereby fostering a more acute musical perception.

\section{Conclusions}

All in all, the integration of traditional music culture into college vocal music teaching is of great significance. It not only enables the effective inheritance and promotion of the traditional music culture of the Chinese nation, but also improves the quality and effect of college vocal music teaching to a certain extent, thus cultivating more vocal talents with high comprehensive literacy and strong professional ability. Therefore, teachers should pay more attention to traditional music culture and actively integrate them into the vocal music teaching curriculum, so that students can have a better experience and feeling in the classroom.

\section{Conflicts of Interest}

The author declares no conflicts of interest regarding the publication of this paper.

\section{References}

[1] Zhi H. (2020). The Significance and Practice of Integrating Vocal Music Teaching into Traditional Music Culture in Colleges and Universities. Journal of Jinan Vocational College, (01): 52-54.

[2] Lin M.M. (2020). A Probe into the Integration of Traditional Music Culture in Vocal Music Teaching in Colleges and Universities. Journal of Jiamusi Vocational Institute, 36(09): 155-156+159.

[3] Li L.L. (2019). An Analysis of the Thinking of Integrating Traditional Music Culture into Vocal Music Teaching in Colleges and Universities. Daguan (Forum), (02): 136-137.

[4] Wang J.M. (2019). The Reason for the Disconnection between Traditional Music Culture and College Vocal Music Teaching and Analysis of Its Integration Strategy. Northern Music, 39(07): 250-251. 